Article

\title{
Simulating Littoral Trade: Modeling the Trade of Wine in the Bronze to Iron Age Transition in Southern France
}

\author{
Stefani A. Crabtree ${ }^{1,2}$ \\ 1 Department of Anthropology, Washington State University, P.O. Box 644910, Pullman, WA 91164, USA; \\ stefani.crabtree@wsu.edu; Tel.: +1-509-335-3441 \\ 2 Maison des Sciences de l'Homme et l'Environnement, Université de Franche-Comté, 32 Rue Megevand, \\ 25030 Besancon Cedex, France; Tel.: +33-3-81-66-51-51
}

Academic Editors: James Millington and John Wainwright

Received: 1 December 2015; Accepted: 27 January 2016; Published: 5 February 2016

\begin{abstract}
The Languedoc-Roussillon region of southern France is well known today for producing full-bodied red wines. Yet wine grapes are not native to France. Additionally, wine was not developed indigenously first. In the 7th century B.C. Etruscan merchants bringing wine landed on the shores of the Languedoc and established trade relationships with the native Gauls, later creating local viticulture, and laying the foundation for a strong cultural identity of French wine production and setting in motion a multi-billion dollar industry. This paper examines the first five centuries of wine consumption (from $\sim 600$ B.C. to $\sim 100$ B.C.), analyzing how preference of one type of luxury good over another created distinctive artifact patterns in the archaeological record. I create a simple agent-based model to examine how the trade of comestibles for wine led to a growing economy and a distinctive patterning of artifacts in the archaeological record of southern France. This model helps shed light on the processes that led to centuries of peaceable relationships with colonial merchants, and interacts with scholarly debate on why Etruscan amphorae are replaced by Greek amphorae so swiftly and completely.
\end{abstract}

Keywords: Languedoc; Gaul; agent-based model; trade; economics; Lattes; Lattara

Niketas then asked for some wine and poured a cup for Baudolino. "See if you like this. It's a resinous wine that many Latins find disgusting; they say it tastes of mold." Assured by Baudolino that this Greek nectar was his favorite drink, Niketas settled down to hear his story. — from Baudolino [1]

\section{Introduction}

Understanding the choices that people made in the past is difficult, if not impossible, without written sources directly telling us why people chose specific courses of action. Yet it is these choices that led to the archaeological record; today we can see the aggregate of these decisions. The following model presents a simple case of examining prehistoric economies. Through using an agent-based model on a heterogeneous population it is suggested that the economy of this area was driven by the choices of Gauls as consumers, and not by the availability of goods; this work articulates with longstanding debates in the prehistory of France.

This research specifically asks the question: what caused the complete switch in wine amphorae from Etruscan to Greek styles in the Languedoc when clearly both groups were present on the landscape? This model aims to examine the abrupt transition from Etruscan amphorae to Greek amphorae as discovered by Py [2] and reported in Figure 1 by modeling strictly local processes. A pattern oriented modeling approach [3] was used to examine the overall process and validate the 
model with the archaeological record. Validation in this model is via a complete shift in artifact types from Etruscan to Greek amphorae-output from the simulation is directly compared against output from the archaeological record. This research is one of the first forays into formal modeling of the archaeological record in France, thus this article represents both the utility of agent-based modeling for examining the prehistory in France, and also acts as a first step for more complex models on French prehistory.

The article is organized as follows. First, a brief background situates the research and the research question. Next, methods and then the model is presented; please note that much of the model detail is described in the supplementary ODD protocol to allow for a streamlined description. Results follow, focusing on those outputs that directly facilitate comparison with observed archaeological phenomena. Following the results of the model, a lengthy discussion of the cultural history of southern France is presented, showing exactly how this model articulates with research in this area. Much of the data on this region is published in French; thus this article provides a summary of the culture history in English, advancing understanding for this area for the Anglophone audience. Finally, the archaeological data are discussed in conjunction with the results presented here, and suggestions to future directions are presented.

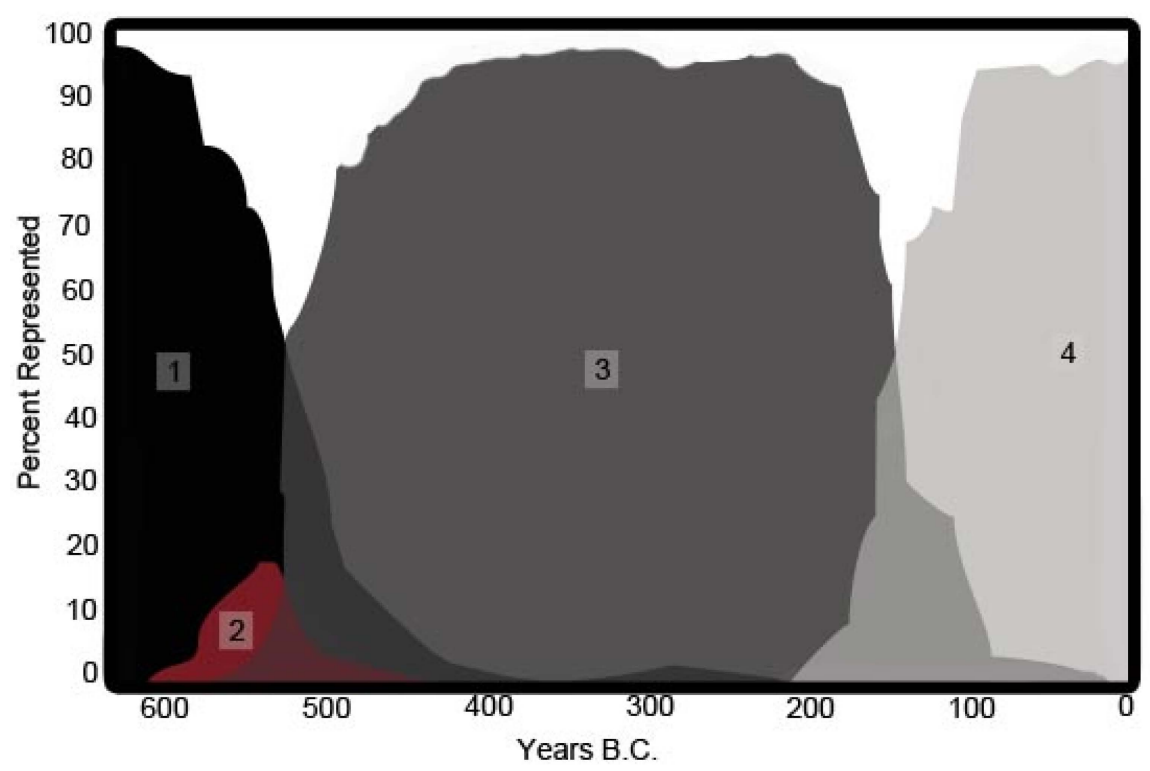

Figure 1. Redrawn from Py [2], curves of artifact percentages through time. (1) represents Etruscan amphorae, which make up almost $100 \%$ of the assemblage at that time. (2) represents archaic Greek amphorae, which have a small percentage of the assemblage. (3) represents Greek amphorae. Note that while Greek amphorae are the dominant form of wine vessels after 500 B.C. that amphorae of Etruscan type (1) are still present into the 3rd millennium B.C. (4) represents Roman amphorae, which are not examined in this paper.

\subsection{Background}

The Languedoc-Roussillon region of southern France (Figure 2) is well known today for producing full-bodied red wines. Yet wine grapes were introduced in antiquity. In the 7th century B.C. wine-bearing Etruscan merchants landed on the shores of the Languedoc and established trade relationships with the native Gaulish elite. In fact, most wine consumed in southern France was not even grown by Gauls, instead being imported to Gaulish settlements [4,5]. In complement to this, some argue that certain colonial settlements were so large they outstripped their local carrying capacities, and thus had to import grain and other comestibles [5]. Complex economic partnerships linking Gauls to Etruscan and later to Greek merchants were essential, yet these trade relationships 
had far-reaching effects for the household economies of both indigenous and colonist populations. "Greek [colonist] towns in general and Greek houses in particular, constitute evidence of a new type of materialism, individualism and consumer display, where patron-client relations were negotiated in semi-public homes, in which creators of wealth were linked to local and international business opportunities" [6]. In this paper, I examine how the trade relationships between colonist merchants and the indigenous Gaulish elite facilitated the development of complex economies and created distinctive artifact patternings in the archaeological record.

This model examines three processes: (1) the arrival of wine-bearing merchants in Gaul; (2) the establishment of trade relationships between these merchants and native Gauls; and, (3) the replacement of Etruscan wine amphorae by Greek wine amphorae. To understand the establishment of trade between Gauls and colonial merchants we need to understand why Gauls would engage in trading grain for wine. Then, to understand the replacement of one amphora type by another, we need to examine the choices made by the Gaulish elite at home. After all, Gauls were the agents of demand in the supply chain. As in the above quote, the preference for one type of wine over another would influence how people would choose to consume wine. Agent-based modeling is a perfect method for examining how local decisions could affect overarching patterns of artifact distributions.

The agent-based model presented here looks at the distribution of artifact types over time across a simplified landscape. By reducing the model to a few key parameters, I am able to directly examine how a preference for one type of wine over the other might affect archaeological assemblages. This model articulates with current debates over the nature of trade within this region. As I discuss below, ethnic identities in the past are difficult to identify, but patterns of artifacts across space and through time can be identified. This simple agent-based model acts as a first step to understanding economies in prehistory and sets up studies that can further examine land use in the past.

Existing models for the interaction between Gaulish inhabitants and colonial traders along the littoral (the region abutting the Mediterranean) of southern France are descriptive. According to Py [7] the paradigms underlying research by proto-historians working in these contexts can be summarized as follows: indigenous Gauls living along the littoral zone were forced to abandon some of their traditional practices, such as semi-nomadic pastoralism, to generate the agricultural surplus required to develop their economies and engage in trade with outsiders [7]. Yet these descriptive models have not been formally tested; thus, the research here formally examines how early colonialism can create distinctive economic partnerships and artifact patterns.

The terms "colonist," "colonizer," and "colonialism" come with academic baggage. To avoid confusion, and differentiate the colonization in southern Gaul from Colonialism in the 1600s-1900s, I will use the term "settled nonlocal merchants," "settled merchants," or simply "merchants" henceforth to refer to the Etruscan and Greek merchants. Settled, because in general the colonizers who arrived in southern Gaul settled in colonies, or in already established Gaulish settlements, as is argued for the Etruscans at Lattara [5]. Nonlocal, because the first wave of Etruscans and Greeks were born in other areas. (Through time this becomes debatable, as later generations of merchants may have been born in Gaul [5].) And finally I use the term merchants, because the Etruscans and Greeks who came to southern Gaul are characterized by engaging in trade with the locals.

How the development of agricultural surplus could lead to trade relationships with merchants is directly examined in the model presented here. By creating multiple parameters related to flows of exchange and the ability to extract resources (discussed in more detail below) and sweeping across values for these parameters I can directly examine existing conceptual models for southern Gaul. To state it simply, this model directly examines how trade affects the survivability of agents on the landscape and allows for the examination of the percent of different artifacts on the landscape. I examine this model in two steps: (1) a simple model allowing for the exchange of wine for grain; and (2) a model that allows for two types of merchant populations, Etruscans and Greeks, to trade with the Gauls for grain. 


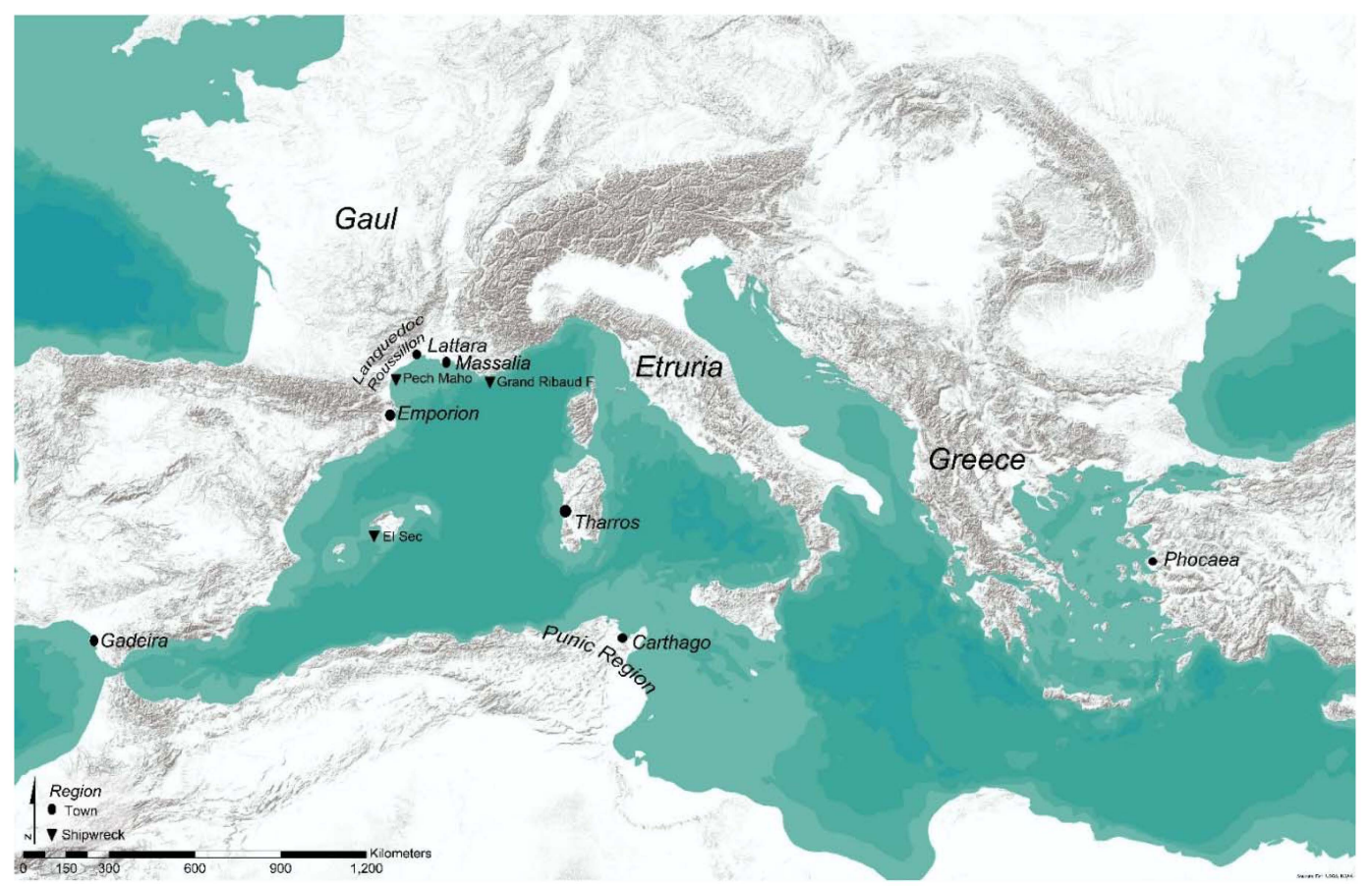

Figure 2. Area of interest for this study. This study specifically examines the development of viticulture and trade in the Languedoc Roussillon region, but map includes surrounding areas of interest to this study. Here I show those cities that are specifically mentioned in this manuscript, as well as the three shipwrecks mentioned that show integration of ethnic identities.

\subsection{Methods}

The agent-based model developed in this paper was created in NetLogo [8], though could have easily been created in any other modeling platform; figures were created in R [9]. The modeling framework consists of a simple resource extraction model coupled with a trade model (see below). Each timestep of the model represents one year and the model is run for 500 timesteps. Two types of output are generated: populations of agents (Gauls and merchants) and populations of artifacts (Etruscan and Greek wine amphorae).

This model is meant to reproduce patterns for validation. While no reliable population estimates exist for this area, patterns of agent survival are helpful in calibrating whether or not exchange of grain for wine would have enabled merchant survival in prehistory. Patterns of artifacts, however, are more reliable in this study area. Output of the quantity of Etruscan and Greek amphorae are compared against real archaeological patterns of artifacts (Figure 1) to determine if local processes could have led to the archaeological record.

\subsection{The Model}

Here I ask two questions: (1) could visiting merchants have survived in the littoral without farming grain? and, (2) can a transition in the number and type of amphorae be generated through modifying a simple set of parameters? I examine these questions through the simple agent-based model detailed below. Following I describe the base of the model to provide a background for the questions answered in this paper, then I detail each of the models.

\subsubsection{The Landscape}

The landscape is 80 -cells by 80 -cells wide, creating a total of 6400 cells for the simulation window. In this model the landscape is created in three portions: the sea to the south ( 2400 cells), the littoral 
region abutting the sea (320 cells; light green in Figure 3), and the rest of the land (3680 cells; medium green in Figure 3). Grain (energy) can only be grown on green patches.

At simulation instantiation a random 33\% subset of the farming landscape is unproductive. Regrowth "clocks" are set on each cell randomly between 0 and 60 years and the patches regenerate during this time. While the model presented here does not use realistic paleoproductivity estimates [10], the random generation of unproductive cells creates a patchy environment that farming Gauls likely faced when they began cultivating wheat. As stated above, the conceptual model used by proto-historians [7] suggests that Gauls abandoned semi-nomadic pastoralism to create surplus for trade. It is likely that not all Gauls would have abandoned this way of life immediately, suggesting that some parts of the landscape would still be in use for pastoralism and foraging. Moreover, lanscape productivity may have been effected by generations of landscape use before settled farming took hold. Thus it is reasonable to expect that not all of the land was available for farming right away. Further, agent actions degrade the landscape (see below) which makes Gaulish agents need to learn to be able to farm, reproduce, and trade.

The decision to abstract the landscape to a rectangular space was made to enable an examination of the simple process of exchange without having to model multiple historical details. Archaeology and historical study has been ongoing in this region for decades. An agent-based model would not be able to encapsulate all of the specifics of the historical record of this region. Moreover, as this is the first agent-based model to be made in this region, it was determined that it would be best to create a highly simplified model with the goal of adding complexities later.

\subsubsection{The Agents}

There are two main types of agents in this model: Gaulish agents and Merchant agents. In this model, agents correspond to the economic production unit of a household [10]. The composition of households may have been slightly different for Gauls than for the Etruscan and Greek visiting merchants, and may have differed depending on social status. For example, on arrival in southern France many of the visiting merchants were likely single men who later may have married locally to create a family or returned home and brought their families from their home countries to the west [5]. For simplicity, in this model it is assumed that agents are independent economic production units. As such, each agent produces goods specific for its type: Gauls produce grain, and Etruscans and Greeks produce wine.

In this model households can be of varying size, and this is tied to production (see below). It is assumed here that the basic household may begin with only one agent-for example, when merchants land, a household consists of one merchant. As households increase their grain storage, they can support more individuals. Then, as households fission and split their grain storage, they can support fewer individuals within their own household from their storage. So household size fluctuates as storage fluctuates, and as daughter households bud off of the parent household. This is explored below in the discussion of grain consumption rates.

To examine how the trade of grain for wine helped the survival of visiting merchants, we need to understand consumption rates of grain in the Gaulish world. Gras [11] identified average consumption rates of roughly six hectoliters $(h l)$ of grain per year for adults. I use this as a base value for consumption by the agents, with four $h l$ of grain as the base for juveniles. In the simulation, if a Gaulish agent has below $10 \mathrm{hl}$ of grain, the household can only support one individual. This scales up as agents store more grain (Table 1). Average annual yields of fields have been suggested to be up to eight $h l$ per hectare [5], so I use this upper bound to calibrate consumption rates and field productivity in the simulation. To calculate the size of family farms I use estimates by White [12] who reports that small farms in the Roman republic, which used similar farming techniques, were between 18 and 108 iugera or 4.5 to 27 hectares during the 5th century B.C. (contemporaneous to this study). The amount of grain harvested also scales with the size of the family; a small family can harvest from 5 hectares, while a large family can harvest up to 15 hectares. This is explained below in Table 1. 
Wine cultivation, however, does not scale with a larger family. In this simulation individuals can harvest 10 amphorae of wine per cell and do not create more viticulture cells with increased family size. Rather, an agent owns one cell of wine production. While amphorae in antiquity varied in size, in this simulation I assume that the amphorae are the standard Attic size of roughly 50 liters of wine per transport amphora [13]. When I discuss trade rates below, the optimum trade is $40 \mathrm{hl}$ of grain for $5 \mathrm{hl}$ (10 amphorae) of wine.

Table 1. How storage level affects the number of individuals in a household and their consumption rates. This enables agents to increase their family size, and thus the productivity of their land, as well as increasing the ability to trade. However, once an agent trades, its storage level will be cut in half (as half is donated to the daughter household) decreasing the household size in the process. Merchants have a higher storage level because they cannot grow their own food, and thus need to plan more to be able to raise daughter households.

\begin{tabular}{cccccc}
\hline $\begin{array}{c}\text { Storage Level } \\
\text { Merchants }\end{array}$ & $\begin{array}{c}\text { Storage Level } \\
\text { Gauls }\end{array}$ & $\begin{array}{c}\text { Size of Plots } \\
\text { Gauls }\end{array}$ & $\begin{array}{c}\text { Size of } \\
\text { Harvest } \\
\text { Gauls }\end{array}$ & $\begin{array}{c}\text { Consumption } \\
\text { Rates Gauls } \\
\text { and Merchants }\end{array}$ & $\begin{array}{c}\text { Corresponding } \\
\text { Number of } \\
\text { Individuals } \\
\text { per Household }\end{array}$ \\
\hline$<45 \mathrm{hl}$ & $\leqslant 10 \mathrm{hl}$ & $5 \mathrm{ha}$ & $40 \mathrm{hl}$ & $6 \mathrm{hl}$ & 1 \\
$\geqslant 46,<50 \mathrm{hl}$ & $>10, \leqslant 30 \mathrm{hl}$ & $5 \times 1.5(7.5 \mathrm{ha})$ & $60 \mathrm{hl}$ & $12 \mathrm{hl}$ & 2 \\
$\geqslant 50,<60 \mathrm{hl}$ & $\geqslant 31, \leqslant 40 \mathrm{hl}$ & $5 \times 2(10 \mathrm{ha})$ & $80 \mathrm{hl}$ & $16 \mathrm{hl}$ & 3 \\
$\geqslant 61,<70 \mathrm{hl}$ & $\geqslant 41, \leqslant 50 \mathrm{hl}$ & $5 \times 2.5(12.5 \mathrm{ha})$ & $100 \mathrm{hl}$ & $20 \mathrm{hl}$ & 4 \\
$\geqslant 71 \mathrm{hl}$ & $\geqslant 51 \mathrm{hl}$ & $5 \times 3(15 \mathrm{ha})$ & $120 \mathrm{hl}$ & $24 \mathrm{hl}$ & 5 \\
\hline
\end{tabular}

Consumption rates are tied to various parameters, including the basic consumption of grain (6 hectoliters per year, per adult) plus the quantity of grain required for planting and harvesting (see below). While farming yield, amount consumed, and exchange rate are all parameterized, in this run of the simulation these parameters were fixed for simplicity. Fixed parameters are reported in Table 2. Of note, planting calories and harvest calories are both set to 4 hectoliters. Gauls would have needed to store seed to plant their fields each year, and planting would be energetically costly. Thus the parameter "planting calories" encapsulates both the stored grain, and the cost to plant a large field. Harvests, on the other hand, are known to come in at once and need to be harvested rapidly before the grain falls off the stalk. Thus Gauls likely relied on neighbors (and potentially slaves, see Discussion) to help with harvest, and may have fed them to help with this cost. Further, some grain that grew may be lost in harvest, due to improper techniques, harvesting too late, or storing improperly. Thus "harvest" encapsulates the costs associated with harvest and storage. Swept parameters are reported in Table 3.

At the beginning of the simulation-here set to year 0, but corresponding to roughly year 700 B.C.-Gaulish agents are distributed randomly on the land portion of the landscape. Each Gaulish agent is created with a storage of grain set to 20 hectoliters. The initial number of Gaulish households is set to 150. Colonist agents are seeded on the landscape during their birth years (Table 2) with $60 \mathrm{hl}$ of grain in storage, and the initial number of colonists is set to 100 .

In this model agents have yearly basic metabolic needs which are met by consuming grain (Table 1). If agents get to zero energy, they die. There is an additional parameter, "life expectancy," that ensures agents-the natal household - do not live too long. If an agent reaches above the number of timesteps set by "life-expectancy" they have a 50\% chance of dying every timestep. (Note that agents can die before that due to lack of resources.) In this sweep life expectancy was set to 80 timesteps since birth; while this is likely a high estimate for antiquity, this allowed many agents to die of "natural" causes (e.g., having too few grain) before being killed off by the simulation. Reproduction in this model is via fission (see Supplementary materials). Daughter households form near their parent household, and storage is divided evenly between daughter and parent households. 
Consuming wine decreases harvest costs (and is consumed at a rate of one unit per year). Elsewhere, beer parties are used as a form of payment to help in collective labor [14]. Alcohol mobilizes workers at work-parties, and was likely used in Gaul for harvest, since crops would mature and need to be harvested quickly. Historians have suggested that beer parties indeed aided in Gaulish grain harvest [15]. For this simulation I apply the concept of beer parties and assume that consuming wine would decrease costs to the harvester. Therefore, having wine is beneficial for farming agents, as it makes harvesting less costly for them.

Table 2. Fixed parameters used in this simulation. Many of these were tested in earlier sweeps, which are not reported here.

\begin{tabular}{|c|c|c|}
\hline Parameter Name & Value & Explanation \\
\hline Grain Storage (Gauls at birth) & $20 h l$ & $\begin{array}{c}\text { Amount of grain per Gaul when seeded } \\
\text { on landscape }\end{array}$ \\
\hline Grain Storage (Merchants at arrival) & $60 \mathrm{hl}$ & $\begin{array}{c}\text { Amount of grain per merchant when } \\
\text { seeded on landscape }\end{array}$ \\
\hline Wine Storage (Merchants at arrival) & 20 amphora & $\begin{array}{l}\text { Amount of wine per merchant when } \\
\text { seeded on landscape }\end{array}$ \\
\hline Number Gauls Seeded & 150 & Number of Gauls at start of simulation \\
\hline Number merchants seeded (both types) & 100 & Number of merchants upon arrival \\
\hline Life expectancy & 80 & $\begin{array}{c}\text { Year after which agent has } 50 \% \text { probability } \\
\text { of mortality per timestep }\end{array}$ \\
\hline Etruscan arrival & Year 34 & Year Etruscans arrive \\
\hline Greek arrival & Year 100 & Year Greeks arrive \\
\hline Grain harvest amount & 20 & $\begin{array}{c}\text { Amount of grain (in hectoliters) harvested } \\
\text { per farmed cell }\end{array}$ \\
\hline Wine harvest amount & 10 & $\begin{array}{c}\text { Amount of wine (in amphora) harvested } \\
\text { per cultivated cell }\end{array}$ \\
\hline Planting calories & $4 h l$ & How much it costs to plant each year \\
\hline Harvest calories & $4 h l$ & How much it costs to harvest each year \\
\hline Wine decay rate & 1 amphora/yr & How much wine rots per year \\
\hline Wine drinking rate & 1 amphora/yr & $\begin{array}{l}\text { How much wine an agent can consume } \\
\text { per year, per type }\end{array}$ \\
\hline Reproduction & $3 \%$ & Probability of reproduction per timestep \\
\hline Probability of selling wine (merchants) & $5 \%$ & $\begin{array}{l}\text { Probability a merchant will be able to sell } \\
\text { wine each time step }\end{array}$ \\
\hline Probability of buying wine (Gauls) & $1 \%$ & $\begin{array}{l}\text { Probability a colonist will be able to buy } \\
\text { wine each time step }\end{array}$ \\
\hline
\end{tabular}

Table 3. Parameters swept across in two models. Grain Trade Rate was swept across in first model. Preference was swept across in second model.

\begin{tabular}{ccc}
\hline Parameter Name & Values Swept Across & Explanation \\
\hline Grain Trade Rate (examined in part 2.1) & 20:10;30:10; 40:10; 50:10, 60:10 & $\begin{array}{c}\text { Amount of hectoliters of grain } \\
\text { traded per 10 amphorae of wine }\end{array}$ \\
\hline Preference (examined in part 2.2) & $0,10,20,30,40,50,60,70,80,90,100$ & $\begin{array}{c}\text { Weighted value for when two } \\
\text { types of wine are available. } \\
\text { Explained further in Table 3 }\end{array}$ \\
\hline
\end{tabular}

Agents trade wine for grain, and trade is costly. Both the wine and grain traded would need to be transported between exchanging agents, so agents are charged calories for the trade of these goods across the simulation in a manner similar to Crabtree [16]. Further, wine was likely an elite drink, and so the trade of grain for wine could only be accomplished by the elite. Thus, agents must account for costs when trading. In this model agents calculate the distance between themselves and their trading partner. The agent that is buying is charged $0.25 \mathrm{hl}$ per cell traveled. This, then, ties to the agent's move algorithm. 
In this model cells degrade after 5 years of farming use; cells become productive again after up to 5 years lying fallow, set randomly. If a Gaulish agent's farm cell has become unproductive, the agent must move to another cell. When Gauls move, they will look at their most recent trading costs and assess how costly they were. If the trading costs were greater than $1 / 4$ of the gain in storage, the agent will move to a productive cell closer to the merchant settlements. If the costs were less than $1 / 4$ of the agent's grain storage, the agent will simply look for another productive cell in a radius of 10 cells to begin a new farm. The Gaulish agent is charged $1 \mathrm{hl}$ to move to a new farm.

Trade in this model is simple, but occurs both from the Gaulish side and from the Merchant side (see Supplementary Material: ODD Protocol, Scheduling). Gaulish agents trade before merchant agents do (demand for goods comes first). When Gaulish agents have stored twice the trade rate in the simulation (in Section 2.2 set to $40 \mathrm{hl}$ ) they may choose to trade for wine. This threshold is so that if an agent reproduces (dividing energy equally) it will have 40 energy to divide between itself and offspring after trading energy for wine; this threshold minimizes agent-death. Merchant agents require grain to survive and reproduce; thus a merchant will always trade for grain when approached by a Gaulish agent asking for wine. The agent that instantiates trade pays the cost for trading as described above [16]. After Gaulish agents trade and complete their scheduling, merchant agents trade.

Second, merchant agents trade wine for grain. When colonist agents have greater than 10 wine-units, they ask a Gaulish agent to trade following the above logic. The merchant agent asks a Gaulish agent to trade; the Gaulish agent then has a 50\% probability of accepting this trade. If the trade is accepted, the merchant agent pays the cost of trading ( 0.25 energy multiplied by the number of cells separating it from the Gaulish agent).

Following I now describe the differences in each model, building from the simplest base model that examines the trade of grain for wine with one type of merchant-agent, to the more complicated model that examines the trade of two types of wine for grain. I additionally discuss the results from running sweeps of each model-type.

\section{Results}

\subsection{Base Model}

In this section I use the base model to establish the trade rate of grain to wine to be used in the subsequent model. While future applications of this model may enable agents to barter for an appropriate trade rate [17], this model sought to reduce variables, so a global exchange rate was determined in this first step. This model examines the verbal model as explained by Py [2], that Etruscan merchants arrived in Gaul and influenced an intensification of agriculture in the area, with Gaulish people creating surplus to engage in trade for wine with the Etruscans. Here I specifically examine population of Etruscan agents, since their survival depends on their ability to trade with Gaulish agents. In this model I calibrate the amount of grain traded, which then feeds into the following models. For this model I specifically ask:

Could Gauls have generated enough surplus to feed visiting merchants, while still enabling their own survival?

Here only farming Gauls and Etruscan merchants exist, so only grain (energy) and one type of wine are traded.

Five exchange rate values were examined (Table 2): a rate of $2: 1,3: 1,4: 1,5: 1$, and 6:1. Value of 1:1 and 7:1 were examined; at 1:1, Etruscan merchants died out quickly (as they do in 2:1), while at 7:1 Gaulish agents died out quickly, which caused the simulation to stop. The basal amount of trade each year is 10 amphorae of wine, so the amount of grain scales accordingly (e.g., 40:10, which equals $40 \mathrm{hl}$ of grain for $5 \mathrm{hl}$ of wine). In summary, colonist agents cannot survive unless they trade wine for grain. Figure 3 reports the response of population to these trade values. 

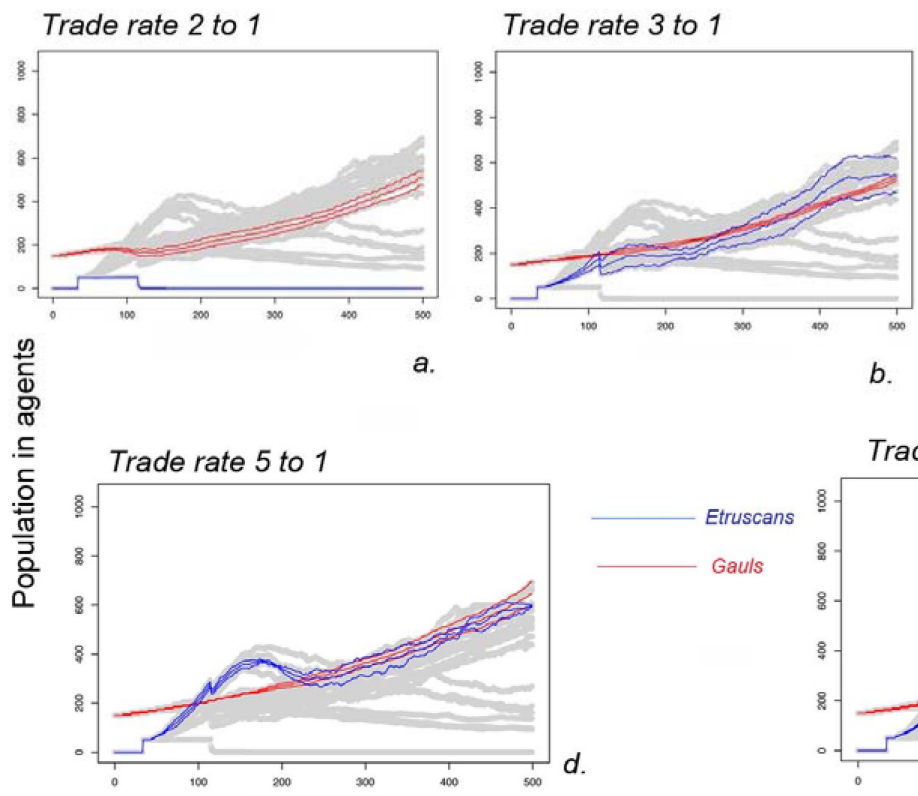

b.

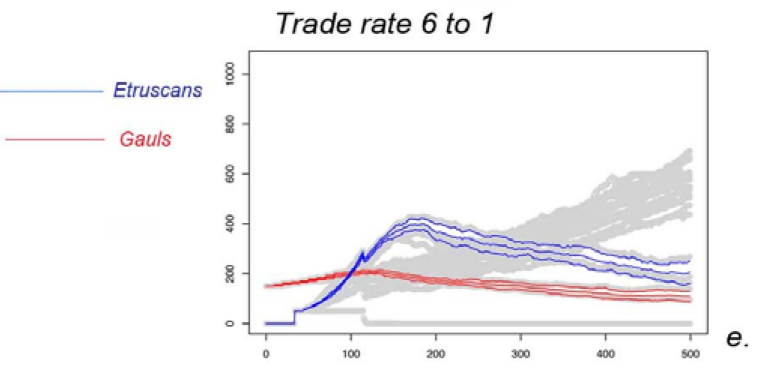

Time in Years

Figure 3. Population response in the simulation, tied to the consumption of grain (grey lines). Solid lines denote the mean population for the scenario being examined, dotted lines denote one standard deviation of the mean above and below the mean. Scenarios a through e represented different trade rates examined in this simulation.

In Figure 3a. I examine the trade of 20 hectoliters of grain for 10 amphorae of wine. Note that merchant-agents die out almost immediately. In Figure 3b. the trade rate (3:1) is more favorable to merchant populations, and their population trajectory reflects this. Note there is large variance around the mean. In Figure 3c. the trade rate (4:1) is increasingly favorable for merchant populations, with their population trajectories more-or-less overlapping by year 300. In Figure 3d. the trade rate (5:1) is again favorable to merchant populations, and the two population trajectories have significant overlap, as with Figure 3c. However, the variance around the mean is larger in Figure 3d. than Figure 3c. In Figure 3e. Gaulish agent populations begin to die out due to the unfavorable trade rate (6:1). This may reflect the trade-rates that some merchants attempted to achieve reported by Diodorus Siculus [18]. This poor trade rate negatively effects merchant populations as well; with fewer Gauls to trade with, the quantity of available grain diminishes, decreasing merchant population.

While many of the trade rates examined here would have enabled the survival of merchant populations in southern France, a trade rate of $40 \mathrm{hl}$ of grain for $5 \mathrm{hl}$ of wine (4:1) creates a favorable exchange rate for both merchant and Gaulish populations, while reducing variance around the mean (reducing path dependence). Thus a trade rate of 4:1 was set for the subsequent models examined in this paper.

Though this model is highly simplified, by using historically reported yield rates ( $8 \mathrm{hl}$ of grain per hectare, with family farms from 4.5 to 27 hectares, consumption of $6 \mathrm{hl}$ of grain annually per adult, and $4 \mathrm{hl}$ per child, $50 \mathrm{l}$ of wine per amphora) it shows that Gauls would have been able to grow enough grain to support themselves and a burgeoning economy. This has important ramifications, and will be discussed below (Discussion). Using these historical rates reported above for average field productivity and average farm size, it is completely feasible that a household would be able to produce enough grain for immediate consumption, storage, and trade. Then, through the trade of wine for grain, merchant populations were able to reproduce and grow their numbers, establishing colonies along the littoral, and engaging in long-term trade with Gaulish farmers. This model verifies Py's first hypothesis [7]. Next, I build on this simple model to examine how the inclusion of two different 
types of merchant populations effects the distribution of artifact types across the landscape, and the survivability of each type of agent.

\subsection{Multiple-Colonist Model}

At the beginning of this article I quote Eco [1], who illustrates the preference of one type of wine for another. While Eco writes of 12th century Italy, the preference for red wines from Etruria, or for wines that are "bitter" and "tasting of mold" would have governed purchasing tactics by prehistoric consumers. In this second simple model I show how these preferences create distinctive artifact patternings that can then be compared to real archaeological data. The model presented in this section builds on the simple trade model presented in Section 2.1. In this model Gaulish agents choose to trade for either Etruscan or Greek wine.

Gaulish agents will favor buying wine according to the parameter, "preference." Preference governs the choice between Etruscan and Greek wine, weighting the probability of choosing a Gaulish or Etruscan wine depending on the perceived value by Gauls. Of course, before Greek agents arrive, Gaulish agents will only purchase Etruscan wine, and thus preference has no effect. Preference can take many forms. Preference could be for the taste of the wine, the rarity of it (causing it to have higher prestige status), or in mimicking the elite [19]. When preference is set to 50, Gaulish agents have a 50\% chance of choosing Etruscan or Greek wine (they don't prefer either, they just want wine). The closer the value is to 0, the more weighted it is in favor of Etruscans, while the closer it is to 100 the more weighted it is in favor of Greeks. These are explained below in Table 4.

Table 4. Preference Values swept across in this study.

\begin{tabular}{ll}
\hline Preference & Explanation \\
\hline 0 & Weight is entirely in favor of Etruscan Wine \\
10 & Weight is strongly in favor of Etruscan Wine \\
20 & Weight is in favor of Etruscan Wine \\
30 & Weight is slightly in favor of Etruscan Wine \\
40 & Weight is very slightly in favor of Etruscan Wine \\
50 & There is no weighted preference between Greek or Etruscan wine. \\
60 & Weight is very slightly in favor of Greek wine. \\
70 & Weight is slightly in favor of Greek wine. \\
80 & Weight is in favor of Greek wine. \\
90 & Weight is strongly in favor of Greek wine. \\
100 & Weight is entirely in favor of Greek wine. \\
\hline
\end{tabular}

Eleven preference values were swept across (reported in Tables 3 and 4) to examine how a simple change of preference could influence both the survival of agents on the landscape and the artifact assemblage across the landscape. Each of these models was run for a total 30 runs per preference value, creating a sweep of 330 runs. Results are reported in Figures 4 and 5. In these figures the average population per each preference value is reported along the left column while the average number of artifacts of each type through time is reported along the right column; solid lines indicate the mean of all runs, while the dotted lines indicate the high and low standard deviations around the mean. It should be noted, however, that even though Gaulish agents may prefer one type of wine over the other when they initiate purchase, each merchant agent initiates trade with a Gaulish agent after the Gaulish agent has finished its scheduling (see Supplementary Information). The Gaulish agent then has a $50 \%$ chance of choosing to trade with the merchant or not. Thus, while preference should affect the results, it should not completely control the assemblage types, and even when Gaulish agents prefer one type of wine over another, due to the logic in this simulation, merchant agents should be able to survive, albeit in low numbers, since merchants can initiate trade as well. 

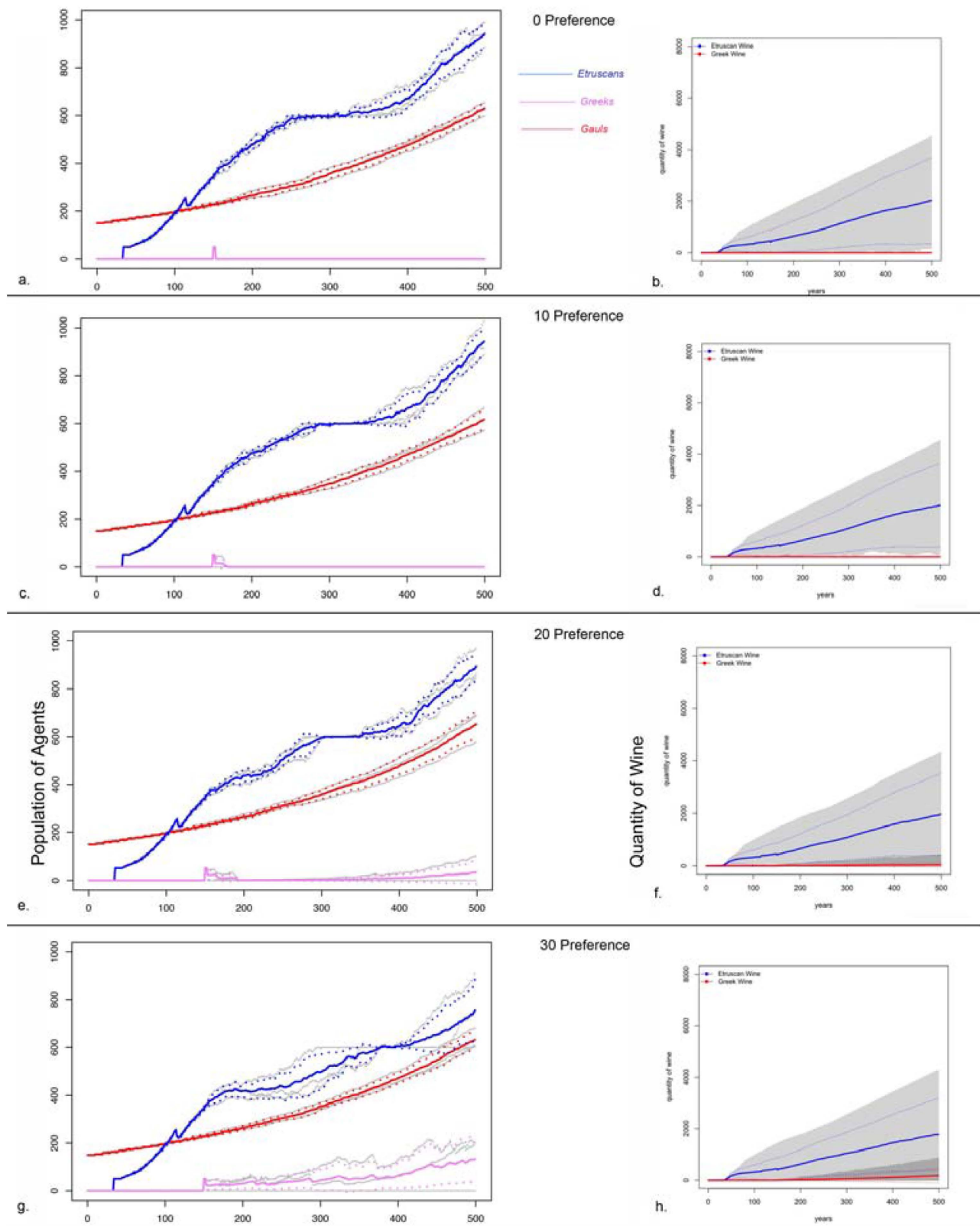

30 Preference
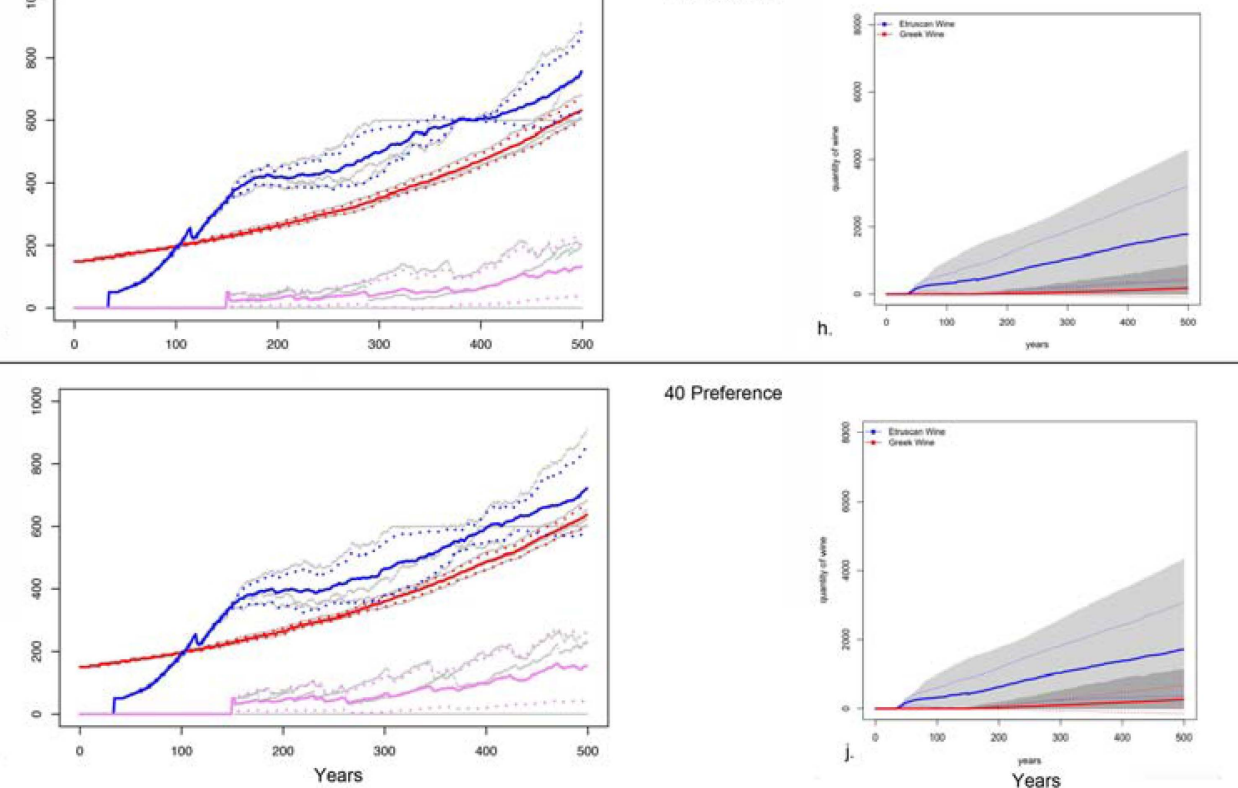

40 Preference

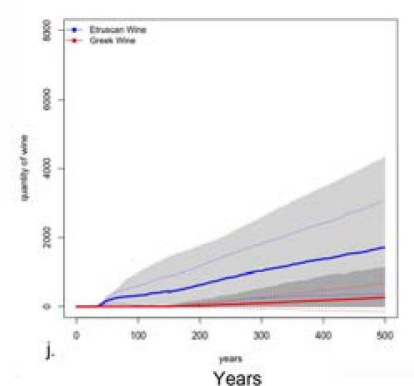

Figure 4. (a-j) Response of population and artifact type based on preference value, beginning with a preference of 0 (in favor of Etruscans) and ending at a preference value of 40 (almost equal preference, still in favor of Etruscans). Preference values are reported in the middle of each tile, corresponding to the values on the left and the right. Left side of tiled figure corresponds to population, while the right side corresponds to the artifact assemblage. Solid colored lines denote the mean, while dotted colored lines denote one standard deviation above and below the mean. Grey lines indicate overall variation of output in simulations. 
In Figure 4, preference is set initially so that Gaulish agents prefer Etruscan wine (preference 0, Figure $4 a, b)$. In this model, Greek agents have difficulty establishing trade relationships with native Gauls (Figure $4 \mathrm{~b}$ ) and die out essentially upon arrival (Figure 4a). The same occurs when preference is set to 10 (Figure 4c,d); when preference is set to 20, Greek agents survive slightly longer, but still die out (Figure 4e,f). This type of situation may be expected when a strong economic partnership develops between two entities, making it difficult, if not impossible, for a new competitor to enter the market. The new goods may be seen as "strange" (e.g., they may "taste of mold" [1]) and thus not desirable. Moreover, the new product may not offer anything better than the older products, and the lack of a relationship between the new sellers and the buyers may influence the sale of those products [20].

As we move down preference values in Figure 4, Greek agents are able to survive easier as the preference value approaches $40 \%$. Yet even in Figure $4 \mathrm{i}$ the population of Etruscans holds strong even after Greek agents arrive. In Figure $4 \mathrm{j}$ it is evident that the slight preference for Etruscan wine over Greek wine influences the distribution of artifacts so that Etruscan amphorae are more prevalent.

In the next set of tiled figures, response of population when preference is set at $50 \%$ is examined (Figure 5a,b). When Gauls weight Etruscan and Greek wine evenly, both Etruscan and Greek wine are present. However, since Etruscans arrive sooner in this simulation (during year 34) they have a longer time to establish trade relationships with Gauls and reproduce along the littoral. Thus, when Greek agents arrive, Etruscan agents outnumber them. The low proportion of Greek wine in the assemblage shows that, while Greek merchants can (and do) trade wine for grain, the quantity reflects the challenge for Greek merchants to gain a foothold in the region.

When preference values begin to favor Greek merchants (Figure $5 c, d$ ) the average number of Etruscan agents and Greek agents stays similar, yet because Etruscans were on the landscape longer they maintain the majority of amphorae (Figure 5d). Only when preference reaches a value of 80, and Greek agents dramatically outpace Etruscan agents (Figure 5g) do the mean number of Greek amphorae begin to be more numerous than Etruscan amphorae (Figure 5h). When preference is set to a value of 90, the mean number of Etruscan amphorae levels out (Figure 5i) showing that the growth of grapes and trade of wine is at a strict replacement rate for the amphorae that are being discarded. Finally, when preference values are set to 100, we see both Etruscan population dying out (Figure 5k) and attrition of Etruscan vessels decrease their presence in the simulated assemblage (Figure 51).
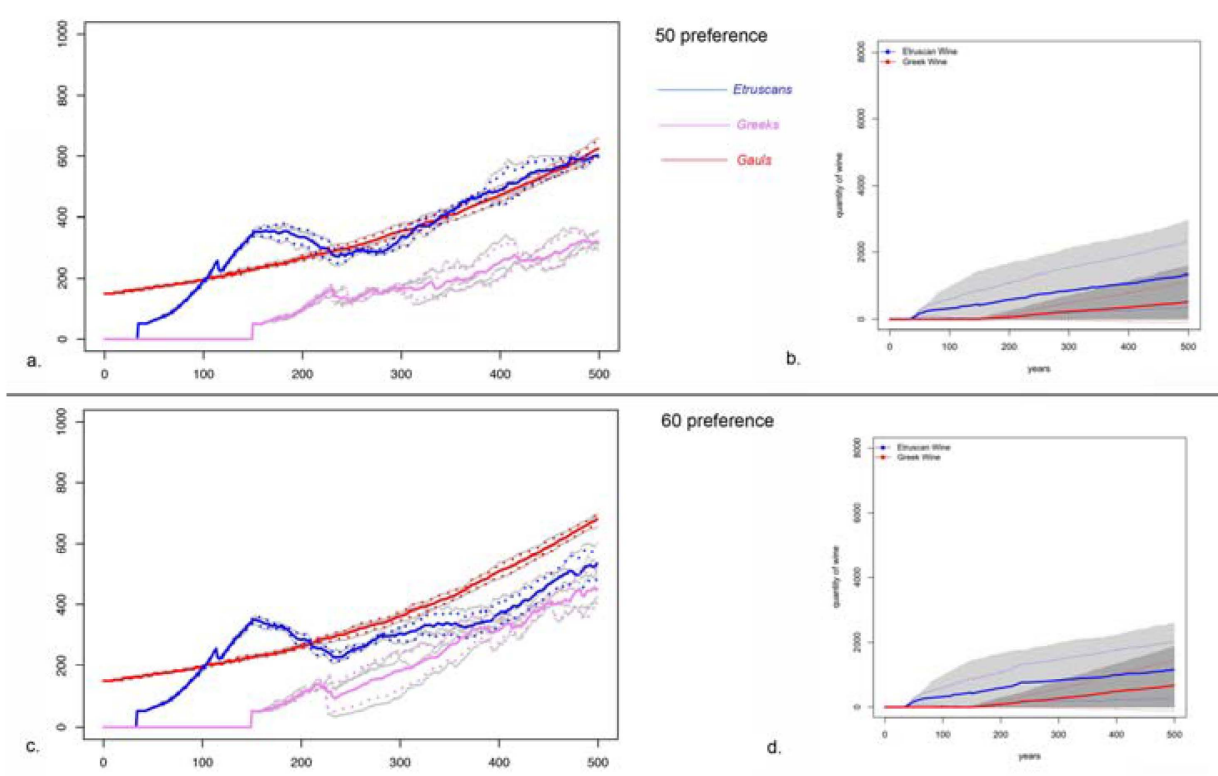

60 preference

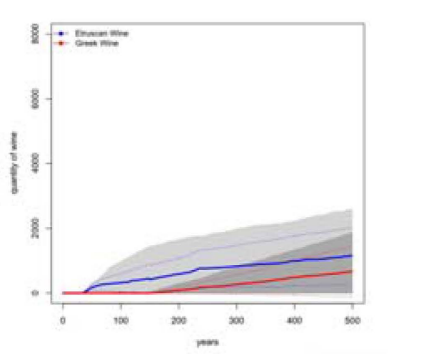

Figure 5. Cont. 


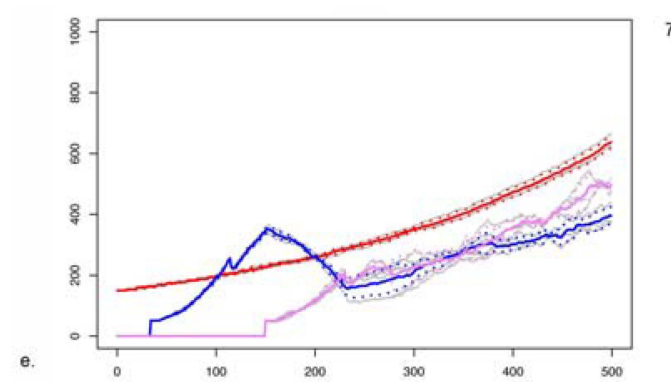

70 preference
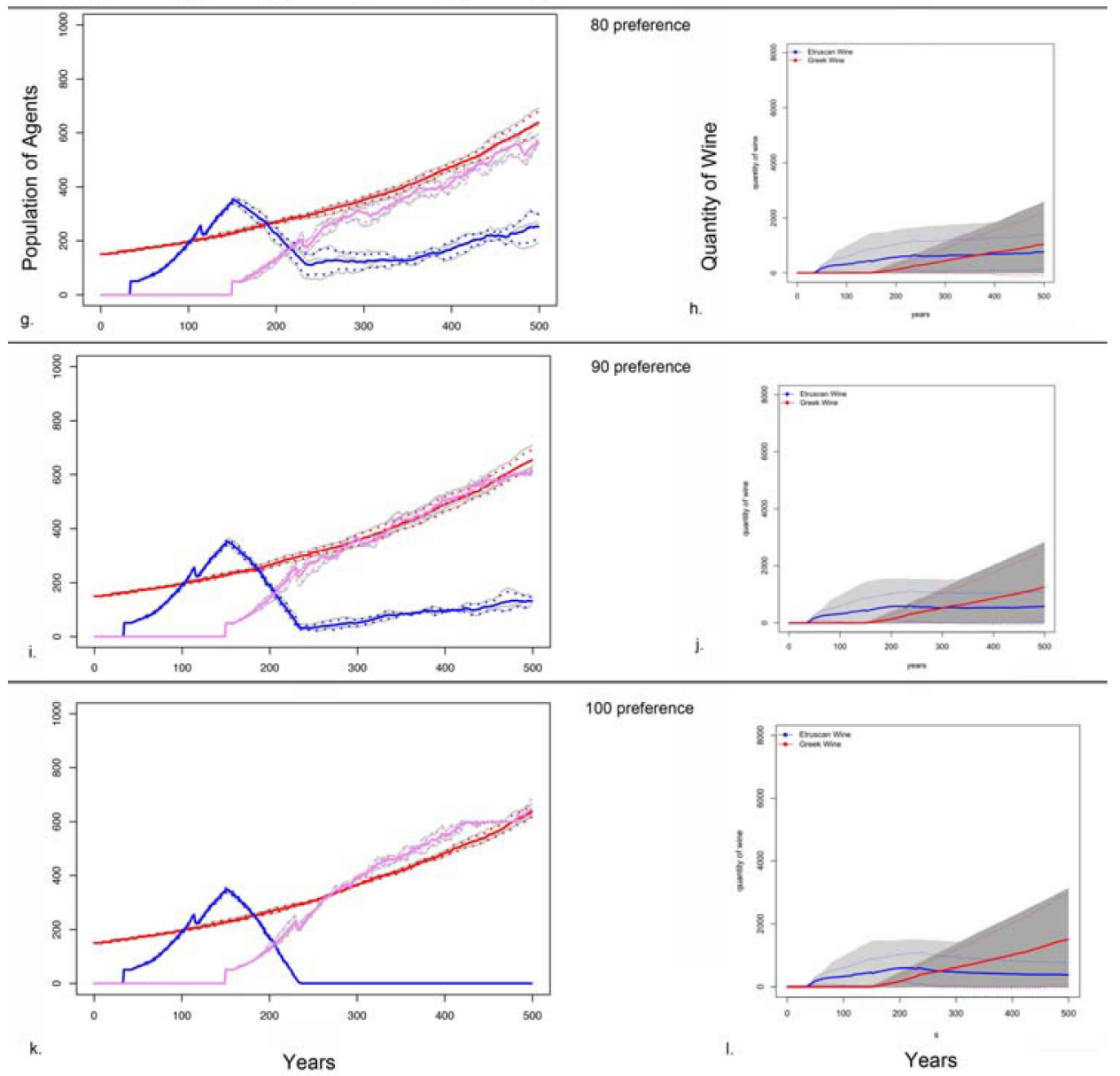

100 preference

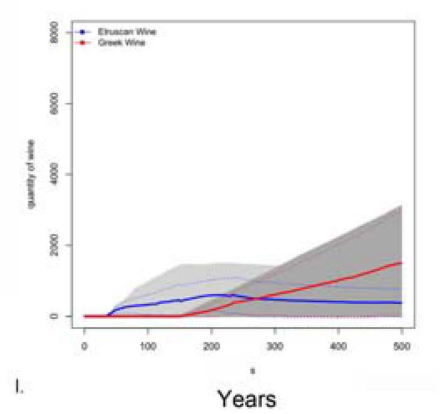

Figure 5. (a-1) Response of population and artifact type based on preference value, beginning at preference of 50 (no preference for Greek or Etruscan wine) and ending at 100 (preference for Greek wine). Preference values are reported in the middle of each tile, corresponding to the values on the left and the right. Left side of tiled figure corresponds to population, while the right side corresponds to the artifact assemblage. Solid colored lines denote the mean, while dotted colored lines denote one standard deviation above and below the mean. Grey lines indicate overall variation of output in simulations.

In Figures 4 and 5 each of the 11 preference values is displayed, demonstrating how preference affects both the distribution of artifacts on the landscape and the survival of each of the agents types on the landscape. Here a phase transition at preference value 30 is evident (Figure 4g,h), after which Greek agents are able to survive and trade. Below this value it is difficult for Greek agents to survive since Gaulish agents have a strong preference for Etruscan wine. Further, since Etruscans arrive first on the landscape, they are able to monopolize the market and establish their own territories.

The next phase transition occurs at a preference value of 70 (Figure 5e,f) where the mean quantity of Greek wine begins to approach that of Etruscan wine by year 400 (Figure 5f); in this scenario the 
mean population of both Etruscans and Greeks is quite similar from year 250 onward. Then, when preference values are set to 80 and 90 Greeks do well, yet Etruscans do not die out. While their populations diminish, they still exist. This is in stark contrast to when preference was set to 10 or 20; in those scenarios, since Etruscans had already established a monopoly on the economy, Greeks were unable to trade enough (or quickly enough) to reproduce. When preference values are set to 80 and 90 , in contrast, Etruscans have already lived on the landscape long enough to create storage and establish trade relationships with the Gauls. They can weather a few years of bad trade relationships due to their longevity in the region. It is only when a preference value of 100 is used that Etruscan merchants completely die out. Indeed, their die off is precipitous and complete by year 250 (Figure 5k).

When Figures 4 and 5 are compared to Figure 1, we can see that it is Figure $5 \mathrm{~h}-1$ that most closely resemble Figure 1; when Gauls "prefer" Greek wine, Greek wine amphorae begin to outnumber Etruscan amphorae even though Etruscans can still trade wine for grain. While it should be noted that the consumption/decay rate built into the simulation decreases the amphorae at a rate of 1 amphora per agent per year, these rates likely reflect use (and discard) in prehistory. Many amphorae were reused, yet many more were recycled when they became cracked or chipped (or perhaps even unfashionable).

Prehistoric France was littered with amphora sherds, and not necessarily because of the ravages of time. (Indeed, modern France is still littered with these amphora sherds). Instead, archaeological evidence suggests that humans who lived during the time examined here ( 700 B.C. to $\sim 100$ B.C.) recycled amphorae as paving gravel, as chips for building walls, as fill for creating land (such as building an artificial hill), or as roof tiles for buildings [21]. If objects were cherished, they would be preserved; consequently, we should see those objects lasting for generations in the archaeological record. Yet if objects are not cherished, and instead are utilitarian, utilitarian objects that outlasted their utility (or became unfashionable) would be discarded. In the simulation amphorae are discarded when the wine is drunk, but also there is no inheritance when an agent dies. Consequently, when an agent dies all of its amphorae are discarded (metaphorically recycled into roof tiles or paving sherds). Thus the new generation will drive the demand for certain types of amphorae due to the practicality of recycling. The artifact curves examined in Figure 1, and recreated in Figure 5h-l, reflect an evolving preference by Gaulish consumers for Greek wine.

However, even though Greek wine replaces Etruscan wine in the simulation, the discard rate of Etruscan sherds in Figure $5 \mathrm{~h}-\mathrm{l}$ is much slower than in Figure 1. This suggests that the use and discard rate in prehistory is much faster than what was used in the simulation. In reality, Etruscan amphorae were used and discarded quickly, suggesting that these amphorae were not treasured objects, but utilitarian vessels that had more use when recycled than being reused in their original form.

This pattern - of a replacement of one type of amphora by another-has been mystifying archaeologists in this region for decades. The model presented here provides a way forward to examine how Gauls drove the economy, and created the archaeological assemblage seen today by their preference for one type of wine over another. Thus, pattern oriented modeling, where I sought to create a virtual artifact assemblage through simple rules of exchange, helps to illuminate the complex processes of prehistoric decision-making and prehistoric economies. Further, as will be discussed below, while archaeologists can identify the amphora, the objects the amphorae were traded for are missing. This model proves that merchant agents, if they did not engage in farming practices (which was likely, see below) could trade local farmers for grain, and through this trade they could survive along the littoral. Thus through creating patterns of artifacts, and examining how the trade of grain for wine effects the survival of merchant agents, I conclude that Gauls drove the economy, but their desire for luxury wine and their willingness to farm enough grain for trade enabled the survival of merchant agents (both Eturscan and Greek) along the littoral.

Of interest, however, is the fact that Etruscan merchants do not die out in Figure 5g,i. Rather, they persist until the end of the simulation. This is explored below with archaeological data on the persistence of different ethic identities of merchants well into the Iron Age in Southern France. 


\section{Discussion}

When an entity creates a monopoly on a type of good, a dramatic and complete switch to another type of that good is suspect. From archaeological data what is clear is that Etruscan amphorae become replaced by Greek amphorae in a rapid amount of time. In the following data (Section 3.2, Trade with Outsiders) I suggest that this is not because Etruscan merchants were not present along the littoral. Rather, Etruscans were present, and their wares were represented alongside those brought by Greek merchants. If these were both present, how would one dominant type of amphora become completely replaced by another?

If one artifact type is technologically superior it may gain a higher quantity of the market share; it may be tempting to suggest that Greek wine, or at least Greek amphorae, were superior. However, it is not necessarily always the case that a technologically superior good will become dominant. Technologically superior goods can be expensive, and if other more readily accessible goods are still at hand, replacement makes little sense. Rather I suggest that it is the desire for a different type of material that creates the switch. Otherwise, both should be present, since some individuals will continue to use (consume) the older material.

In the above model I show phase transitions at $30 \%$ and $80 \%$. Here, it is not necessary for $100 \%$ of Gauls to prefer one type of wine over another. Rather, when an individual prefers Greek wine 1 out of every 5 times, Grecian merchants are able to stake a stronghold along the littoral. Thus, this model demonstrates that it is not necessary for $100 \%$ of the populace to prefer buying one type of wine over another, but rather that critical transitions happen at percentages much less than $100 \%$.

Further, recall that these results are for the demand side. Etruscan and Greek merchants can still approach Gaulish agents and ask to sell. While Gauls will only accept buying 50\% of the time when they are approached, even then this pattern of complete artifact replacement is present. This shows how important the demand side is for the supply-demand chain of Gaulish consumption (discussed further below) and demonstrates the agency Gauls had in shaping their economies.

\subsection{Archaeological Evidence: Mixing of Colonial Entities}

Modern conceptions of nationalist trade ventures likely do not hold for trading in antiquity; Greek and Etruscan merchants likely coexisted and traded each others' wares. This is evident in recovered vessels from shipwrecks. De Hoz [22] notes that the El Sec shipwreck (Figure 2), dating to the 4th century B.C., contained a vast array of types of amphorae, 30 percent of which came from Samos (Figure 2), with Punic and Greek graffiti present on the recovered vessels [22,23]. This mixing is present in other contexts, such as the Grand Ribaud F shipwreck (Figure 2) where Etruscan and Greek goods are both represented [24], and on a lead tablet inscribed with both Greek and Etruscan text, recovered at Pech Maho in western Languedoc (Figure $2[5,25]$ ). The replacement of amphorae from Etruscan-type to Greek-type does not necessarily mean that ethnically identified Etruscans were no longer present in Gaul, or that Etruscans were no longer producing goods to trade. The replacement rather indicates that there was a cultural shift from wanting Etruscan wine vessels to wanting Greek wine vessels, and likely the contents within them, too. Etruscans and Greeks were present simultaneously, yet vessel-type changed rapidly. Understanding Gauls as drivers of the economy may help illuminate the transition to Roman amphorae that occurred much later (Figure 1).

\subsection{Trade with Outsiders}

The Gaulish littoral was not isolated, but had contact with traders well before the development of the complex exchange networks noted archaeologically. For example, Punic traders interacted with Gauls in the Languedoc since at least the 8th century B.C. $[7,26]$. However, these interactions were short and established no high-intensity trade relationships. Objects of Punic origin, including amphorae, vases, and glass objects are present in Gaul beginning in the 7th century B.C. However, no evidence for Punic settlement is present. While Punic boats likely made frequent trips across the 
Mediterranean to Languedoc [7], these interactions left ephemeral traces. Further, Villard [26] notes that Gauls in a small settlement in what would become Massalia likely had contact with merchants from Phocaea, an Ionian Greek city on the western coast of Anatolia, a half century before the founding of Massalia as a Greek city (contemporary Marseille, see Figure 2; Villard [26] places the foundation of Massalia between 600 and 596 B.C.)

Ceramics for the transportation and drinking of wine arrive in southern Gaul by the late seventh century B.C. These ceramics are composed primarily of Etruscan wine amphorae, although Etruscan bucchero nero pottery, as well as a small quantity of Greek ceramics (likely imported by Etruscans) are also present (Villard notes roughly 30 of these in Marseille [26]).

Once Massalia was founded, locally produced fine-wares called "Pseudo-Ionian" and "Grey Monochrome" began to be produced (although Villard remarks that the massaliote and imported ceramics are fundamentally the same, just made in different areas [26]). Some of these wares were traded to indigenous peoples. Villard [26] finds a wider range of fine-ware ceramic vessels in Massalia than in indigenous settlements; it appears that ceramics at indigenous sites include only wine-related vessels to complement indigenous bowl forms, while in Massalia ceramics take on more numerous forms. Additionally, wine begins being produced locally in the littoral, such as at Massalia by Greeks [27]. After c. 525 B.C., local imports of Etruscan amphorae fell off sharply as Massalian-produced amphorae replaced them [27]. However, Villard also notes that the imported amphorae from Greece are much more abundant in Massalia than locally made amphorae, postulating that "imported wine was more or less consumed where it arrived, even while locally grown and produced wine was largely exported [locally] into the indigenous market" [26] (my translation).

Thus, the pattern of trade between Gauls and visiting nonlocal merchants shows that Gauls received almost exclusively pottery related to drinking wine. These included amphorae and wine-drinking apparatus. Yet ceramic assemblages from other areas that traded with Etruscan and Greek merchants show a higher diversity of objects. If Gauls drove the demand for Greek wine, we may be able to expect to see in the archaeological record evidence for Gauls driving other areas of their economy. This is examined below.

\subsection{Supply and Demand}

Morel [28] states that contemporary trade between Etruscans and North Africans does not follow the same pattern as that between Etruscans and Gauls. Rather, southern Gaul's limited type of imports likely reflects consumer demand more than the range of artifacts available. Specifically, the artifact type "amphorette," a ceramic object used for storing high quality wines less than half the size of an amphora [29], makes up approximately half of the bucchero nero pottery in Carthage, almost $100 \%$ of pottery in Tharros (a city on the western coast of Sardinia, see Figure 2), but is "practically inexistent" in Gaul [28]. Table wine and wine amphorae are the objects the Gauls desired and do not reflect the variety of objects offered for trade by the Etruscans; rather the makeup of Gaulish assemblages reflect a cultural preference for drinking materials. As Dietler [15] states, Gauls "avidly adopted this foreign form of drink while at the same time rejecting other cultural borrowings."

The trade of amphorae seems to be one-way-evidence for Gaulish products in merchant settlements is thin-so secondary measures for identifying the goods traded are often used. For example, historians suggest that Massalia was so large it would have outstripped its local carrying capacity, and only through trade were inhabitants of Massalia able to eat [5]. Coupling this with primary sources, such as Strabo [30] who describes Massalian land as too poor to produce grain, and the suggestion that Etruscan and Greek traders would not have engaged in subsistence farming due to it being seen as below their station [31], grain was likely produced by Gauls and traded to settled merchants. However, this statement had never been tested formally. The model presented above illustrates how the trade of grain could have enabled merchant survival. Further evidence of ships bearing large quantities of grain are recorded as arriving in Greek and Etruscan homelands, and this grain likely came from Gaul [5]. 
Metal and salt are two other commodities likely to have originated in Gaul and traded to settled merchants. Copper, gold, iron, tin and silver are all found within France, and sources for these are noted in antiquity [4]. These metals would have been essential for the creation of objects during the Iron Age, and salt would have been essential for food preservation. Overland transalpine exchange of metals and salts from Gaul to northern Italy began in the early Bronze Age [4], so it is likely that Etruscan traders knew that minerals could be obtained in Gaul, thus influencing their decision to trade in Gaul.

As suggested above in discussion of harvest (Section 2.2), enslaved people were likely present along the littoral. Briggs [4] suggests that Etruscans commonly used enslaved people as servants, and that women and children especially would have been brought to the colonizer homeland as household slaves [4]. While "one of the most elusive of all prehistoric objects of exchange is human labour" [4], the importance of slaves in Etruscan households may suggest that Gaulish women and children were some of the "objects" that enabled the trade system to function [4,5]. Indeed Diodorus Siculus [18] writes that some brazen merchants would attempt exchanging one amphora of wine for one slave. (Though this anecdote relates to the first century BC, and this exchange value was likely not the norm.)

So, while wine amphorae are plentiful in Gaulish settlements [2], the objects for which they were traded remain elusive. Indirect evidence suggests that grain, metals, salt, and slaves were traded to the settled merchants. The model presented above intervenes in these debates. While the objects that were traded may be invisible, the survival of merchants along the littoral suggests that they were able to trade their goods for foodstuffs. This model shows that a simple economic model can enable merchant survival, and can lead to distinctive artifact patterns. While this model is highly simplified, it enables a first step into using agent-based modeling in Southern France, and will be expanded upon the in future to examine expanded economies (such as the trade of metal or salt) and the aggregation of Gauls into oppida.

\section{Future Directions}

I began this article by proposing that a simple preference for one type of wine over another could cause the empirical artifact distribution recognized by Py [2] and reported in Figure 1. To do that, historically-based farming production rates were employed on a simplified landscape to enable the intensification of agriculture and the trade of surplus wine for grain. In this we can examine landscape use in antiquity and see how it could lead to the establishment of complex economies in the past.

Results in this model showed that when Gaulish agents did not prefer one type of wine over another (when preference was set to 50\%) that both Etruscan and Greek wine were present in the simulation, but that Etruscan wine was more common due to being present in the area longer. When preference was set to 20 (Table 4) or below it was very difficult for Greek merchants to trade wine for grain and to exist on the landscape. Additionally, when preference was set to 70 or higher (Table 4), Greek wine supplanted Etruscan wine as the more common type in the simulation (after Greek merchant arrival). However, it was only when preference was set to a value of 100 that Etruscan died off. Even when this occurred, however, Etruscan wine amphorae were still present for the remainder of the simulation due to a slow use and decay rate.

These findings have important implications for the archaeological record. First, these results suggest that when Greek merchants arrived in southern Gaul that their product was found as desirable. If it was not, the archaeological record may reflect those results in Figure 4f-h. Instead, Figure 1 resembles most closely Figure 5i-k, where Greek wine arrived and became common along the littoral. In these figures Etruscan amphorae make up the early assemblage, but are quickly supplanted by a second type of amphora. In the simulation, not only were Greek wines seen as desirable, but upon their arrival they were preferred by Gauls and became the largest part of the assemblage. However, these results also suggest that artifacts can have a long uselife. Archaeological assemblages may not reflect the presence of a population, but may reflect instead the storage and use of those artifacts after a population moves on. 
The work begun here is ongoing, as this simple model was a first step in establishing an agent-based model for the development of colonial interactions in southern France. As mentioned above, multiple other types of resources besides grain were traded for wine. While these scenarios are not examined in this publication, this model is being developed to enable the trade of two types of wine for two types of resources-grain and metal. Future research will examine how the incorporation of diverse resources effects the survival of agents on the landscape and the distribution of materials on the landscape. Research is also being pursued into using realistic GIS dataplanes in the simulation, instead of using a simple patchy and regenerating landscape, as was used in the model presented here. This will enable the development of aggregation models based on least-cost path analysis to help agents trade resources across the landscape and establish settlements at optimal locations to enable trade.

\section{Conclusions}

What drove the preference of Greek over Etruscan wine? Was it the desire for a less expensive product? Was it because Gauls liked the taste of Greek wine better? Did Greek merchants treat Gaulish farmers better than their Etruscan counterparts had? These are not questions that can be answered with an agent-based model, but would rather need to be examined through the archaeological record and through primary texts. However, the model presented here enables us to begin to ask these open questions, since we now know through systematic analysis that preference can drive artifact assemblages. Gauls preferred Greek amphorae, and likely the contents within them, over Etruscan amphorae, and it was through this demand that the artifact assemblage changed so rapidly and completely. If Etruscan amphorae signaled wealth or prestige, archaeologists should see them much later in the archaeological record. Instead they are discarded and recycled to make way for new Greek ceramics.

Debates about the causes of the complete replacement of Etruscan amphorae by Greek amphorae, as reported in Figure 1, are longstanding for this area. This research directly intervenes in these debates. The importance of this work is that the replacement event might be understood from internal, rather than external, processes. While further studies would need to take into account economic decisions-such as Greek amphorae being less costly to produce-this work begins these debates and allows for a thorough and systematic study of the distribution of wine types across the littoral. Further, this simple model shows that using a modeling approach can help shed light on complex processes. This model provides a useful tool to support the hypothesis that it is the demand for wine that drove these artifact patterns, not necessarily the availability of products [26]. Gaulish people were the creators of the economy of southern France, and their preferences drove what we see in the archaeological record.

This model is meant as a first step toward understanding the complexities of early colonist interactions in southern France, as well as a first step toward understanding how France became a viniculture powerhouse. The modern wine industry in France has roots that date back to the founding of the wine trade between Etruscans, Gauls and Greeks, and it is through the development of this complex economy that the wine industry exists today [27]. Even though this model may be simple, it helps advance our understanding of local populations as drivers of the economy of a globalizing antique world.

Acknowledgments: I would like to thank Laure Nuninger, François Favory, Tim Kohler, and Rachel Opitz for guidance in developing this model. Further, I would like to thank Andrew Duff, Kathryn Harris, James Millington and John Wainwright, as well as two anonymous reviewers who helped to edit this work. This work also is indebted to each member of the TransMonDyn research group, who have commented on, guided, and listened to countless versions of this project. This work is also indebted to Michel Py and Michael Dietler, whose foundational work in understanding colonial interactions along this region influenced this model. Crabtree recognizes funding from the NSF Graduate Research Fellowship \#DGE-080667 and the Chateaubriand Fellowship Program for helping fund this work. Crabtree created this model, wrote this paper, and did the analyses herself; any errors or mistakes are strictly her own. 
Conflicts of Interest: The author declares no conflict of interest.

\section{References}

1. Eco, U. Baudolino; Harcourt, Inc.: New York, NY, USA, 2000.

2. Py, M. Culture, Économie Et Société Protohistoriques Dans La Région Nimoise; Publications de l'École française de Rome: Rome, Italy, 1990.

3. Grimm, V.; Revilla, E.; Berger, U.; Jeltsch, F.; Mooij, W.M.; Railsback, S.F.; Thulke, H.-H.; Weiner, J.; Wiegand, T.; DeAngelis, D.L. Pattern-Oriented modeling of agent-based complex systems: Lessons from ecology. Science 2005, 301, 987-991. [CrossRef] [PubMed]

4. Briggs, D.N. Metals, salt, and slaves: economic links between Gaul and Italy from the eighth to the late sixth centuries BC. Oxf. J. Archaeol. 2003, 22, 243-259. [CrossRef]

5. Dietler, M. Archaeologies of Colonialism: Consumption, Entanglement, and Violence in Ancient Mediterranean France; University of California Press: Los Angeles, CA, USA, 2010.

6. Bintliff, J. The Hellenistic to Roman Mediterranean: A proto-capitalist revolution? In Economic Archaeology: From Structure to Performance in European Archaeology; Kerig, T., Zimmermann, A., Eds.; Rudolf Habelt GmbH: Bonn, Germany, 2013; pp. 285-292.

7. Py, M. Les Gaulois du Midi, de la fin de l'Age du Bronze à la Conquête Romaine; Nouvelle édition revue et augmentée, collection Les Hespérides, Errance; 2012.

8. Wilensky, U. NetLogo; Center for Connected Learning and Computer-Based Modeling, Northwestern University: Evanston, IL, USA, 1999; Available online: http:/ /ccl.northwestern.edu/netlogo/ (accessed on 12 December 2015).

9. R Core Team. R: A Language and Environment for Statistical Computing; R Foundation for Statistical Computing: Vienna, Austria, 2013. Available online: http:/ /www.R-project.org/ (accessed on 12 December 2015).

10. Emergence and Collapse of Early Villages; Kohler, T.A., Varien, M.D., Eds.; University of California Press: Berkeley and Los Angeles, CA, USA, 2012.

11. Gras, M. Trafics Tyrrhéniens Archä̈ques; Bibliothèque des Ecoles Français d'Athènes et de Rome 258; Ecole Française de Rome: Rome, Italy, 1985.

12. White, K.D. Roman Farming; Cornell University Press: Ithaca, NY, USA, 1970.

13. Cahill, N. Household and City Organization at Olynthus; Yale University Press: New Haven, CT, USA, 2002.

14. McAllister, P. Xhosa Beer Drinking Rituals: Power, Practice and Performance in the South African Rural Periphery; Carolina Academic Press: Durham, NC, USA, 2006.

15. Dietler, M. Driven by drink: The role of drinking in the political economy and the case of Early Iron Age France. J. Anthropol. Archaeol. 1990, 9, 352-406. [CrossRef]

16. Crabtree, S.A. Inferring social networks from aggregation in, and simulation of, the central Mesa Verde. J. Archaeol. Method Theory 2015, 22, 144-181. [CrossRef]

17. Cockburn, D.; Crabtree, S.A.; Kobti, Z.; Kohler, T.A.; Bocinsky, R.K. Simulating social and economic specialization in small-scale agricultural societies. J. Artif. Sci. Soc. Simul. 2013, 16, 4. [CrossRef]

18. Siculus, D. The Library of History; Volume III, Books 4.59-8; Translated by C.H. Oldfather, Loeb Classical Library; Harvard University Press: Cambridge, MA, USA, 1939.

19. Hashim, M.N.; Che, R.R. Consumer ethnocentrism: The relationship with domestic products evaluation and buying preferences. Int. J. Manag. Stud. 2004, 11, 29-44.

20. Mazzeo, M.J. Product choice and oligopoly market structure. RAND J. Econ. 2002, 33, 221-242. [CrossRef]

21. Twede, D. Commercial amphoras: The earliest consumer packages? J. Macromark. 2002, 22, 98-108. [CrossRef]

22. De Hoz, J. El Sec: les graffites mercantiles en Occident et l'éprave de l'El Sec. Revue des Etudes Anciennes 1987, 89, 117-130. [CrossRef]

23. Koehler, C.G. Corinthian A and B Transport Amphoras. PhD Dissertation, Princeton University, Princeton, NJ, USA, 1978.

24. Rouillard, P. Les Grecs et la peninsula ibérique du VIIIe au IVe siècle avant Jésus-Christ; Broccard: Paris, France, 1992.

25. Chadwick, J. The Pech Maho lead. Zeitschrift für Papyrologie und Epigraphik 1990, 82, 161-166. 
26. Villard, F. La Céramique Grecque de Marseille (VIe-IVe siècle); Essai D’histoire économique; Thèse pour le doctorat ès lettres, présentée à la faculté des lettres de l'université de Paris. Editions e. de Boccard: Paris, France, 1960.

27. McGovern, P.E.; Luley, B.P.; Rovira, N.; Mirzoian, A.; Callahan, M.P.; Smith, K.E.; Hall, G.R.; Davidson, T.; Henkin, J.M. Beginning of viniculture in France. Proc. Natl. Acad. Sci. USA 2013, 110, 10147-10152. [CrossRef] [PubMed]

28. Morel, J.P. Le Commerce Etrusque en France, en Espagne, et en Afrique; L'Eturia Mineraria: Atti del XII Convegno di studi etruschi e etalica; Firenze-Populonia-Piombino, 16-20 giugno 1979; LS Olschki: Florence, Italy, 1981; pp. 463-508.

29. Vallat, P.; Cabanis, M. Le site de "Champ Chalatras" aux Martres-d'Artière (Puy-de-Dôme) et les premiers témoins archéologiques de la viticulture gallo-romaine dans le bassin de Clermont-Ferrand (Auvergne). Revue Archéologique du centre de la France. 2009.

30. Strabo, J. Geography; Volume II, Books 305; Translated by H.L. Jones, Loeb Classical Library; Harvard University Press: Cambridge, MA, USA, 1923.

31. Wood, E.M. Agriculture and slavery in classical Athens. Am. J. Anc. Hist. 1983, 8, 1-47.

(C) 2016 by the author; licensee MDPI, Basel, Switzerland. This article is an open access article distributed under the terms and conditions of the Creative Commons by Attribution (CC-BY) license (http://creativecommons.org/licenses/by/4.0/). 